\title{
Current issues of information technologies application in electric power industry
}

\author{
$J V$ Torkunova $^{1, *}, M N$ Habrieva $^{2}$ and $L V$ Plotnikova $^{1}$ \\ ${ }^{1}$ Kazan State Power Engineering University, 51, Krasnoselskaya street, Kazan, Russia \\ ${ }^{2}$ Kazan branch of the Russian international Academy of tourism, 39, Kosmonavtov street, Kazan, Russia
}

\begin{abstract}
The article considers the problems of IT development in the power industry. During the studies the analysis of the competitive advantages of information technologies was carried out and the following functional features of information systems were revealed: Material Requirements Planning (MRP), Manufacturing resource planning (MRP II), Enterprise Resource Planning (ERP), Enterprise Resource \& Relationship Processing (ERP II), Customer Relationship Management (CRM), Supply Chain Management (SCM). The authors also justify the incentives for the development of intelligent technologies in the electric power industry. The main purpose of the study was to substantiate that management capabilities based on IT create the conditions for innovative development of the industry. The digitalization of the energy sector, intelligent metering and distribution systems for the electric power present new requirements for the training of IT specialists. Analysis of the main current IT trends in the power sector helps to justify the need for the use of the Internet services during laboratory work in the educational process.
\end{abstract}

\section{Introduction}

The development of the electric power industry currently has a number of serious problems such as moral and physical aging of the entire equipment stock, high energy intensity of the supply grid, excessive increase in operating voltage in the network, cross-subsidization in various forms, payment crisis, lack of investment, inefficiency of the management system, etc. The more complex the production is the more acutely it needs more automation of the processes occurring. The use of IT in the field of energy distribution and energy saving can reduce technical losses in the process of electric power transmission, efficiently use generated electricity, diagnose and fix problems with automatic operation, increase the stability of electricity supplies, provide an objective analysis of the efficiency of energy and money consumption [1].

\section{Methods}

The working methods of IT technology in the field of energy conservation are the use of information and communication technologies, automated collection and accounting of information, monitoring the equipment operation and database management. The use of this type of technology allows monitoring the processes of transmission, distribution and consumption of electricity in real time. At the same time, the role of upgrading the system of communication devices and remote control, its integration with modern network equipment is increasing [2-4].
In the modern world, there is a rapid digitalization of this industry. As a part of the National Technology Initiative program, the "EnergyNet" roadmap was recently approved to develop the smart energy market. The implementation of the measures laid down in the roadmap will make it possible to create a $\$ 40$ billion market in Russia by 2035, and Russian IT and telecommunications companies will be able to occupy a worthy place in the world market. The document was created under the leadership of Alexey Texler, First Deputy Energy Minister, and Boris Ryabov, Managing Partner of Bright Capital. By EnergyNet, the authors of the document understand the market of equipment, software, engineering and services for multi-scale integrated systems and services of smart energy. "The best metaphor to describe the market is Internet energy - an ecosystem of energy producers and consumers who seamlessly integrate into the overall infrastructure and exchange energy," reads the roadmap description [5].

\section{Results}

So far, the current technological innovative solutions in the power industry are:

- internet services for monitoring data and metering devices, IT energy management systems, billing.

- automatic dispatch control systems.

- information and analytical energy management systems aimed at the proper use of energy resources.

\footnotetext{
* Corresponding author: torkynova@mail.ru
} 
- creation of IT infrastructure: modernization of server platforms, computer systems in video conferencing

- operation of information and telecommunication systems, use of "maintenance-free" energy-efficient equipment.

- management of maintenance and repairs, logistics

- creation of systems aimed at working with customers of electric power enterprises (CRM-systems) [6].

While IT definitely provides a competitive advantage for the management system, we need to consider first the following defining characteristics of energy management:

- energy resources are considered in inseparable connection with their consumers;

- energy resources are characterized by indicators: safety, reliability, quality, availability;

- energy saving is directly related to the mode of their consumption;

- power supply has a spatial distribution character;

- the energy level of the control object is described by mathematical models and algorithms for the processing of control and accounting information [7].

Based on these features, the role of information technology in automating business processes is difficult to overestimate. High competition requires new progressive solutions. Information technology is a fundamentally new level of business:

- first, this is a new worldview on internal performance and competitive advantages [7];

- secondly, it provides an increase in efficiency, productivity, productivity and speed of work with clients;

- thirdly, it allows improving service quality and reducing costs by automating business processes [8-10].

Currently, there are a variety of modern information systems on the market, which differ in terms of functionality and business requirements. In the field of IT, the most significant from the point of view of practice are the following standards: Material Requirements Planning (MRP), Manufacturing resource planning (MRP II), Enterprise
Resource Planning (ERP), Enterprise Resource \& Relationship Processing (ERP II), Customer Relationship Management (CRM), Supply Chain Management (SCM), Manufacturing Execution System (MES), Enterprise Asset Management (EAM) (table 1).

Table 1 shows that IT have changed the management standards, as all the business processes are optimized, namely:

- MRP (Requirements Planning) is based on the "Make on Time" concept. The task of the MRP system is to minimize the costs associated with warehouse stocks. MRP is designed to solve the following problems: regulating the supply of components of the production process; optimization of work with the nomenclature of materials; ensuring the continuity of the enterprise without the accumulation of excess stocks; organization of daily planning of the material needs of the enterprise;

- MRP II (production resource planning) is a set of principles, models, and management and control procedures. This planning strategy improves the financial and economic performance of the company. The idea of MRP II is based on the principle of demand sharing. The purpose of MRP II is to minimize the frozen funds invested in the purchase of raw materials. The task of MRP II is to ensure the availability of the required number of materials-components, along with the possible reduction of permanent stocks;

- ERP is a business process management system: planning, budgeting, logistics, accounting; personnel management, production, customers. ERP-modules organize a well-established workflow. The modular structure is an important feature of this system. Modules are divided into two types: modules for internal use and modules that work with external users. ERP modules differ from each other in their set of functions: maintenance of technological specifications; demand management and sales planning; material requirements planning; inventory and procurement management; capacity planning; financial accounting, management accounting, operational accounting; project management.

- ERP II is responsible for the company's business strategy, which helps to increase the value of the business at the expense of the latest technologies: it

Table 1. Competitive advantages of IT technologies.

\begin{tabular}{|c|c|c|c|}
\hline $\begin{array}{c}\text { Management } \\
\text { standards }\end{array}$ & Goal & Function & Economical impact \\
\hline ERP & \begin{tabular}{|ll} 
Business & Process \\
Management & \\
\end{tabular} & Workflow organization & Management efficiency growth \\
\hline ERP II & \begin{tabular}{|ll} 
Business & Strategy \\
Management &
\end{tabular} & Formation of customer base & Rising business value \\
\hline CRM & $\begin{array}{l}\text { Customer Relationship } \\
\text { Management }\end{array}$ & $\begin{array}{l}\text { Automatic customer interaction } \\
\text { strategies. }\end{array}$ & $\begin{array}{l}\text { Volume and sale efficiency } \\
\text { growth }\end{array}$ \\
\hline SCM & $\begin{array}{l}\text { Operational Resource } \\
\text { Planning }\end{array}$ & Product Informational Support & Production cost reduction \\
\hline MES & Production Management & $\begin{array}{l}\text { Real time production } \\
\text { management }\end{array}$ & $\begin{array}{l}\text { Optimization of production } \\
\text { processes }\end{array}$ \\
\hline EAM & Asset Management & Production capacity growth & Equipment productivity growth \\
\hline
\end{tabular}


forms the client base, stores and analyzes data, predicts the timing of subsequent orders; provides personalized service; forms a long-term relationship with customers. Using ERP II greatly simplifies and speeds up procurement processes. ERP II includes all the functionality of ERP-systems and the functionality of CRM-systems. The use of CRM functionality in ERP II systems allows creating a personal profile for each client;

- CRM is a customer relationship management system. The task of the system is to automate customer interaction strategies. The CRM system increases the volume of sales, forms an electronic card for each client, where information about him and the entire history of interaction are provided in chronological order. The system can set a reminder for an important meeting, a commercial offer, find out the details of the transaction, issue an invoice for payment. The CRM system is equipped with control tools, thanks to which the user will receive a signal about the order fulfillment;

- SCM is the system that provides resource planning and information support throughout the product life cycle - from the order for its development to the aftersales service and disposal. SCM is a marketing network philosophy in which the right goods will be delivered to the right place at the right time with the lowest cost;

- MES is a specialized high-tech system of operational planning and production management. MES relates to information-computing systems at the local level, namely, they allow optimizing production processes and combining methods and tools for production management in real time (on-line). System functions: operational planning; optimization of production processes; collecting facts; management of technical documents, product quality; personnel management;

- EAM is an asset management systems. EAM allows increasing the production capacity of the company based on: optimizing the size of inventories; cost management; increase the life of the equipment; increase equipment performance; optimization of procurement management; acceleration of equipment repair, etc.

A brief analysis of the competitive advantages of these management standards indicates that the reliability of information technologies and the quality of their support depends on the company's competitiveness, and this increases the requirements for their effectiveness.

Smart technology involves the use of telecommunications and IT skills to create more efficient business systems. The use of smart technologies in the field of energy distribution and energy saving can reduce technical losses in the process of electricity transmission, efficiently use the generated electricity, select alternative energy sources, diagnose and fix automatic operation problems, increase the stability of electricity supply, and reduce carbon emissions. Recent developments in information and communications technology have changed the future of the power industry. For example, installing end-user counters with bi-directional data exchange with the network and with built-in intelligent management tools significantly increased the efficiency of management decisions in the industry [12-14].

The working methods of such systems consist in the application of information and communication technologies, automated collection and accounting of information, monitoring equipment operation, and database management. The use of intelligent power supply networks (ISE) allows real-time monitoring of the processes of transmission, distribution and consumption of electricity. At the same time, the role of upgrading the system of communication devices and remote control, its integration with modern network equipment, is increasing. The technical equipment of the control rooms, their system integration is an important component of the trouble free operation of power systems and their energy efficiency. The study suggests that the development of IT infrastructure is relevant in the following areas:

1) creation of automated integrated management systems that support the provision of the collection and integration of information of the technological process using the database at real time;

2) formation of the IT model of the object to be managed. The object model contains engineering data for all the stages of the product life cycle;

3) solving problems of control, management and analysis of power equipment on the basis of an appropriate model [15].

Smart technologies in the power industry create a more efficient system for managing the process of production, distribution and consumption of electricity in the industry (Table 2).

Table 2. The concept of smart technologies.

\begin{tabular}{|l|l|l|l|}
\hline \multicolumn{1}{|c|}{ Technologies } & \multicolumn{1}{|c|}{ Tasks } & \multicolumn{1}{c|}{ Goals } & \multicolumn{1}{c|}{ Efficiency } \\
\hline $\begin{array}{l}\text { Intellectual } \\
\text { accounting } \\
\text { (Smart Metering) }\end{array}$ & $\begin{array}{l}\text { Installation of smart metering devices } \\
\text { on the consumer side, their regular } \\
\text { survey, data processing and the } \\
\text { provision of information on energy } \\
\text { consumption. }\end{array}$ & $\begin{array}{l}\text { Search, collection, } \\
\text { processing, } \\
\text { storage } \\
\text { necessary data, of }\end{array}$ & $\begin{array}{l}\text { Increases } \\
\text { profitability, } \\
\text { importance, } \\
\text { reliability, service } \\
\text { sustainability }\end{array}$ \\
\hline $\begin{array}{l}\text { Intellectual network } \\
\text { (Smart Grid) }\end{array}$ & $\begin{array}{l}\text { Installation of a managed network that } \\
\text { collects, processes and distributes } \\
\text { information on resource consumption } \\
\text { by market participants }\end{array}$ & $\begin{array}{l}\text { Development of } \\
\text { new information, } \\
\text { solving } \\
\text { optimization } \\
\text { issues }\end{array}$ & $\begin{array}{l}\text { Increases } \\
\text { management } \\
\text { decision efficiency }\end{array}$ \\
\hline
\end{tabular}


From Table 2 we can see that smart technologies allow improving the operation of energy facilities and meeting the criteria of energy efficiency and management decision efficiency.

It is obvious that it is practically impossible to train specialists who possess competences in the listed areas without sufficient equipment and specialized software.

The initial level of such competencies can, for example, be formed by the following disciplines studied at Kazan State Energy University: Networks and Telecommunications, Administration of Corporate Information and Computing Networks, Information Systems and Networks, Design and Maintenance of Local Computer Networks, Installing and Configuring Hardware and Software for Internet Access, Designing information systems, Software information measuring systems and others. However, training should be advanced and knowledge should be given in accordance with the current level of development of IT, which is not observed today, due to the lack of an adequate material base and a weak personnel component.

\section{Discussion}

The main IT tasks of power generation are automation of technological process systems and control over installed equipment. The use of the most advanced technologies by the power generating companies allows increasing labor productivity and ensuring the stability of the equipment. The development of IT in the industry entails more efficient operations of all the control structures.

The main factor that influences the development of information technologies in the power industry of Russia is the need for high-tech reforms in this sector of economy. The introduction of information technologies leads to the integration of accounting for all energy resources and the automation of the settlement system with consumers. Factors stimulating the development of intelligent networks include economic and technical aspects: the multiplicity of energy actors; the need to modernize the energy infrastructure; the need for largescale integration of distributed energy; innovative technologies associated with electrical grid facilities and smart meters; power supply quality; power supply reliability; spatial and temporal complexities of the energy system.

The concept of smart technologies can be summarized by defining the smart power system as the combination of energy infrastructure and information and communication technologies (software, automation, information processing).

For the proper training of IT specialists in the field of electric power industry, it is necessary to create an Internet Services Laboratory on the basis of Kazan Energy University, which should be equipped not only with software, but also with hardware. A good example in this regard is a laboratory equipped by Danfoss specializing in the automation of energy processes.

In the laboratory of such orientation it would be possible to study information technology systems, including control systems, teleautomatics and communications, monitoring and diagnostics (intelligent active adaptive Smart Grid networks, digital substations, etc.).

\section{References}

1. N. Ismail. How technology is revolutionizing the energy sector, https://www.information-age.com/ technologyrevolutionising-energy-sector123468883/

2. T.V. Drozdova, N.E. Elov, Information technology as a tool regional energy solutions in the transition to Smart, Automation \& it in power engineering, 4 , 29-31 (2014)

3. O. Kozlov, Introduction of information technologies in the energy bulletin of Moscow Energy institute, MPEI VESTNIK, 3,59-64 (2006)

4. I.I. Livshitz, A.V. Neklyudov, An information security assessment hybrid methodology for power engineering, Energy security and energy efficiency, 4,5-11 (2017)

5. I. Korolev, NTI: Smart energy is a chance for Russian it and Telecom companies. URL: http://www.cnews.ru /articles/2017-02https://scienceforum.ru/2015/article/2015009878

6. V.V. Cuprian, V.A. Titova, Application of modern information technologies in power industry. URL: https://scienceforum.ru/2015/article/2015009878

7. M.N. Khabrieva, Tools to improve the competitive strength of the organization: Scientific review, 24 458-60 (2015)

8. J.V. Torkunova, Optimization Model of Interactive Forms of Education for Formation Innovative and Research Competence, Procedia - Social and Behavioral Sciences, 191, 1690-2 (2015)

9. J.V. Torkunova, O.I. Bogomolova, I.R. Muhametkalieva, A.R. Fazilanova, Informationanalytical system of monitoring of the level of qualification of personnel, Vestnik Kazanskogo energeticheskogo universiteta, 4, 22-8 (2017)

10. A.M. Bain, E. Jo Zo, A.R. Kasimov, The method of reduction of the intensity of information flows integrated information manadgement systems in the energy sector, The defense complex - scientific and technicalprogress of Rissia, 3,33-7 (2013)

11. M.G. Shishaev, V.V. Dikovitsky, N.V. Nikulina, Architecture and Technologies of KnowledgeBased Multi-domain Information Systems for Industrial Purposes, Automation control theory perspectives in intelligent systems, 5,359-69 (2016)

12. I.N. Lizunov, R.Sh. Misbakhov, I.Z. Bagautdinov, The centralized system of relay protection and automation for substations of medium voltage, 2nd International conference on industrial engineering, Applications and manufacturing (2016) https://ieeexplore.ieee.org/document/7911449

13. A.N. Tsvetkov, A.R. Safin, R.R. Gibadullin, Hardware-Software system test bench for studies of a reciprocating electrical machine, 2nd International conference on industrial engineering, 
Applications and manufacturing (2016) https://ieeexplore.ieee.org/document/7911493

14. E.V. Izmailova, T.O. Politova, V.V. Serov, Development of methods of detection of pipelines corrosion defeat by computer modeling, 2nd international conference on industrial engineering, Applications and manufacturing (2016) https://ieeexplore.ieee.org/document/7911605/

15. L.V. Plotnikova, L.A. Kashipova, Development of software for analysis of the structure of industrial heat and power systems, 2nd international conference on industrial engineering, Applications and manufacturing (2016) https://ieeexplore.ieee.org/document/7911675 